\title{
Induction of Genotoxic Damage in Fish as Revealed by the Micronucleus Test and the Comet Assay Following In Vivo Exposure to Marine Toxin Okadaic Acid
}

\author{
Tolga ÇAVAŞ, Serpil KÖNEN
}

\begin{abstract}
Okadaic acid (OA) involved in Diarrheic Shellfish Poisoning (DSP) is a marine toxin produced by dinoflagellates such as Prorocentrum sp. Although the neurotoxic properties of DA are well documented, very little is known regarding in vivo genotoxicity of OA on aquatic organisms, especially on fish. In the present paper, an in vivo study on the genotoxic effects of OA was carried out on a model fish Oreochromis niloticus using the micronucleus test and the comet assay. The fish were exposed to three different doses of okadaic acid via intraperitoneal injection. Ethyl methane sulphonate (EMS) at a single dose of $5 \mathrm{mg} / \mathrm{l}$ was used as positive control. Analysis of micronuclei, nuclear abnormalities and DNA damage were carried out on peripheral erythrocytes sampled at intervals of 24,48 and $72 \mathrm{~h}$ post treatment. Our results revealed significant increases in the frequencies of micronuclei, nuclear abnormalities as well as DNA strand breaks indicating the genotoxic potential of OA on fish.
\end{abstract}

Keywords - component, formatting, style, styling, insert (key words)

\section{Introduction}

Harmful Algal Bloom (HAB) has been spreading and increasing along the coast over the world in the past two decade. It is known that toxins produced by HABs can cause damage to the marine environment and threat human life. Among these toxins, okadaic acid (OA) is gaining considerable interest since it accumulates in filter-feeding animals consumed by humans [1]. OA is also involved in Diarrhetic Shellfish Poisoning (DSP) in human causes mainly gastrointestinal symptoms as a result of consumption of contaminated seafood. OA was first isolated from two sponge species belonging to genus Halichondria, $H$. okadaii and $H$. melanodocia [2]. Subsequent studies have shown that dinoflagellates from genus Prorocentrum and Dinophysis have also capacity to produce OA $[3,4]$

Dr. Tolga ÇAVAŞ

Uluidag University, Faculty of Sciences \& Arts, Department of Biology Turkey

Dr. Serpil KÖNEN

Mersin University, Faculty of Sciences \& Arts, Department of Biology Turkey
$\mathrm{OA}$ is a tumor-promoting agent that inhibits phosphatase activity and has a conflicting genotoxicity data [5,6] .OA and its derivatives are also known as powerful cytotoxins that can block dephosphorylation of proteins in mammals and plants, but very little is known regarding the effect of these compounds on marine organisms [7].

In the last decade, the development of sensitive biomarkers for detection of genotoxic effects in aquatic organisms has gained importance due to increasing concern over the presence of genotoxic substances in the aquatic environment. Micronucleus test is a widely established biomarker of genotoxicity in fish [8,9]. In the last decade, the formations of morphological nuclear alterations other than micronuclei, such as nuclear buds, in peripheral erythrocytes of fish have been also used as possible indicators of genotoxicity [10,11]. Comet assay, also known as single cell gel electrophoresis (SCG), is a microgel electrophoresis technique which detects DNA damage in individual cells [12].

The objective of this study was to investigate the induction of genotoxic damage in fish following in vivo exposure to OA, using comet assay, micronucleus test and nuclear bud analyses in peripheral erythrocytes of fish Oreochromis niloticus. To our knowledge this is the first study evaluating the in vivo genotoxicity of diarrhetic shellfish poison, okadaic acid, in fish.

\section{Materials and Methods}

\section{Fish and chemicals}

Specimens of Oreochromis niloticus (Pisces: Cichlidade) with an average weight of $10 \pm 1 \mathrm{~g}$ and length of $5 \pm 1 \mathrm{~cm}$ were supplied by the Cukurova University fish farm (Adana, Turkey). Before the experiments they were acclimated under laboratory conditions for 1 month at a population density of 15 specimens in $50 \mathrm{~L}$ aquaria, and $25{ }^{\circ} \mathrm{C} 12 / 12 \mathrm{~h}$ dark/light modes. Fish were not fed during the experiments. Okadaic acid (Figure 1) and all the other chemicals needed to perform the micronucleus test and the comet assays were obtained from the Sigma-Aldrich Chemical Company 


\section{Experimental design}

Fish were placed in aquaria containing dechlorinated tap water. Okadaic acid was dissolved in ethanol. The fish were intracoelomically (i.c.) injected with three different doses (1 $\mu \mathrm{g} / \mathrm{kg}, 5 \mu \mathrm{g} / \mathrm{kg}$ and $10 \mu \mathrm{g} / \mathrm{kg}$ body weight) of Okadaic acid (OA) with acid Ethyl Methane Sulphonate (EMS) which was used as positive control at a concentration of $5 \mathrm{mg} / \mathrm{g}$ body weight. Fish from solvent control group injected with ethanol whereas negative control group were injected with water only. For the micronucleus test, blood samples were obtained on the first, second and third days following the exposure to OA. Five fish were used for each dose/duration group. A total of 75 fish were used for the experiments.

\section{Analysis of micronuclei and nuclear buds}

Peripheral blood samples obtained from the caudal vein of the specimens were smeared onto pre-cleaned slides and were fixed ethanol for $20 \mathrm{~min}$. The smears were than stained with $10 \%$ Giemsa solution for $25 \mathrm{~min}$. For each fish, three slides were prepared and from each slide 2000 cells were scored under $100 \mathrm{x}$ magnification. Small, non-refractive, circular or ovoid chromatin bodies, displaying the same staining and focusing pattern as the main nucleus, were scored as micronuclei (MN) [8]. Small evaginations of the nuclear membrane contained euchromatin were classified as nuclear buds (NB). All slides were coded and scored blind.

\section{The comet assay}

The alkaline comet assay was performed according to the method of Tice et al. [12] with some modification. Blood samples collected from caudal veins of fish were diluted with $1 \mathrm{ml}$ of PBS. $60 \mu \mathrm{l}$ of the diluted sample were mixed with $200 \mu \mathrm{l}$ of $0.65 \%$ low melting point (LMP) agarose. $75 \mu \mathrm{l}$ of the mixture were than layered on the slides precoated with on $0.5 \%$ normal melting point (NMP) agarose and immediately covered with a coverslip and than kept for $10 \mathrm{~min}$ in a refrigerator to solidify. After gently removing the coverslips, the slides were covered with a third layer of $90 \mu \mathrm{l}$ lowmelting-point agarose and covered with coverslips again. After solidification of the gel, coverslips were removed and the slides were immersed in cold lysing solution $(2.5 \mathrm{M} \mathrm{NaCl}$, $100 \mathrm{mM} \mathrm{Na} \mathrm{NaDTA}_{2}$-ED $10 \mathrm{mM}$ Tris, pH 10, with $10 \%$ DMSO and $1 \%$ Triton $\mathrm{X}-100$ added fresh) and refrigerated at $4{ }^{\circ} \mathrm{C}$ for $2 \mathrm{~h}$. After lysis, the slides were placed on a horizontal electrophoresis box side by side. The tank was filled with fresh electrophoresis solution (1 mM Na EDTA, $300 \mathrm{mM}$ $\mathrm{NaOH}$, and $\mathrm{pH} 13.5$ ) to a level approximately $0.25 \mathrm{~cm}$ above the slides. The slides were left in the solution for $20 \mathrm{~min}$ to allow the unwinding. Electrophoresis was performed using the same solution at $25 \mathrm{~V}, 300 \mathrm{~mA}$ for $25 \mathrm{~min}$. The slides were than neutralized gently with $0.4 \mathrm{M}$ Tris buffer at $\mathrm{pH} 7.5$ and stained with $75 \mu \mathrm{L}$ ethidium bromide $(20 \mu \mathrm{g} / \mathrm{mL})$.
Slides were examined using an Olympus BX40 fluorescence microscope. Two hundred cells (100 per replicate) were scored at $400 \mathrm{x}$ magnification. The DNA damage was quantified by visual classification of cells into five categories "comets" corresponding to the tail length [13]. The comet assay data were manually evaluated to calculate the percent of damaged cells and genetic damage index values as previously described $[14,15]$

\section{Statistical Analysis}

After assessing the normality of distribution of the data, both parametric and nonparametric tests were used in order to detect differences at the 0.05 level of significance. Differences between mean values for micronuclei and nuclear buds were compared using the Student's t-test and least significant difference test for the micronuclei data and the Mann-Whitney U-test for the comet assay data.

\section{Results}

Micronucleus frequencies in peripheral erythrocytes of Oreochromis niloticus exposed to $\mathrm{OA}$ as well as parallel negative, positive and solvent controls are demonstrated in Fig. 1. As can be seen from the figure, the micronucleus frequencies significantly increased following with OA treatment $(\mathrm{P}<0.01)$. Treatment with positive control EMS significantly induced the frequencies of micronuclei in erythrocytes $(\mathrm{P}<0.001)$ whereas no significant effect was observed in solvent control group $(\mathrm{P}>0.05)$.

Similarly, analysis of other nuclear abnormalities revealed significant increases in peripheral erythrocytes following treatment with OA $(\mathrm{P}<0.01)$. Results of total nuclear abnormality analyses are demonstrated in Fig. 2. Comparison of $\mathrm{MN}$ and $\mathrm{NB}$ frequencies revealed a strong correlation between the expressions of micronuclei and nuclear buds in peripheral erythrocytes $(\mathrm{R} 2=0.85, \mathrm{P}<0.01)($ Fig. 3$)$.

Fig. 4 and table 1 shows the proportion of damaged nuclei and genetic damage index as measured in the comet assay, respectively. Significant increases in DNA migration was observed in OA exposed group compared to the control fish $(\mathrm{P}<0.01)$. The differences in genetic damage index between exposed and control groups reached statistical significance mainly by the increased percentages of type II, type III and type IV cells in the exposed group. Similar responses were also found in positive control group $(\mathrm{P}<0.001)$. Once again no significant genotoxic effect was observed in solvent control group ( $\mathrm{P}>0.05)$. 


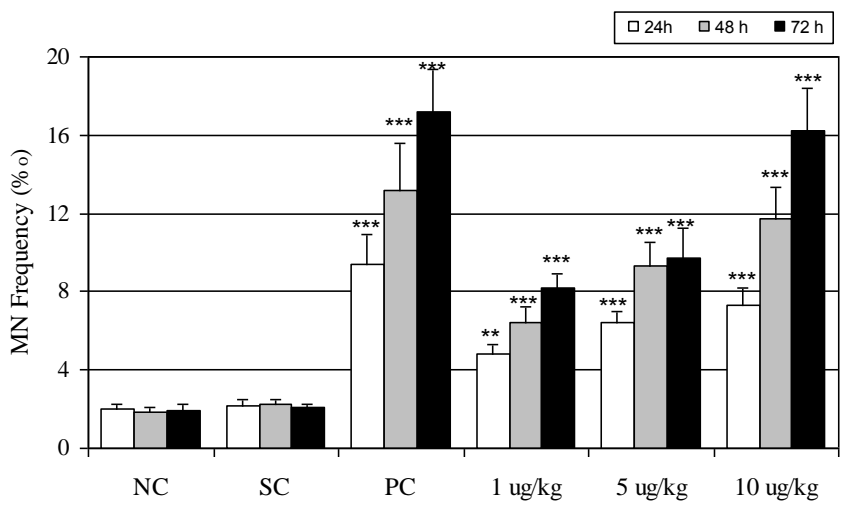

Figure 1. MN frequencies (\%) in peripheral blood erythrocytes of $O$. niloticus treated with Okadaic acid (Mean $\pm \mathrm{SE})$.

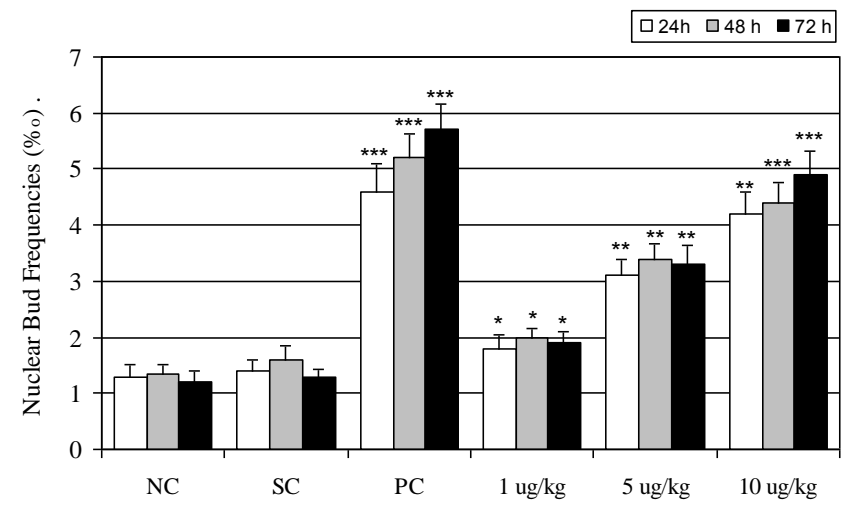

Figure 2. Nuclear bud (NB) frequencies in peripheral erythrocytes of $O$. niloticus intracoelomically injected with okadaic acid. (NC: negative control, SC: solvent control, PC: positive control). $\mathrm{N}=5$ for each dose/duration group.

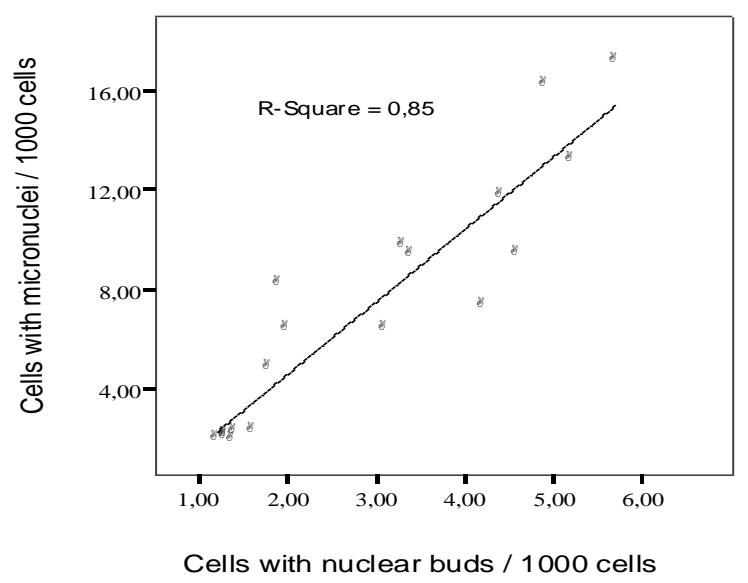

Figure 3. Relation between micronuclei and nuclear bud frequencies in fish.

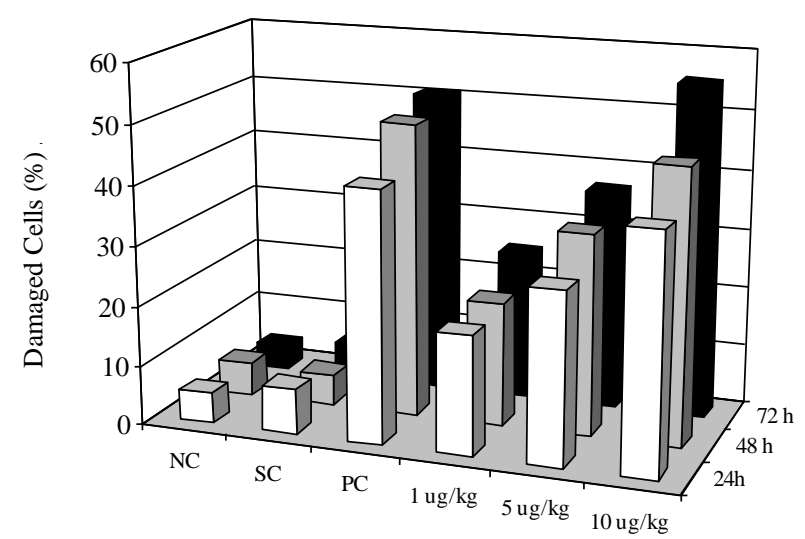

Figure 4. Percentage of damaged cells in comet assay after Palus et al., 1999 (Type II + III + IV).

Table 1. Genetic damage index (GDI) values in peripheral erythrocytes of O. niloticus esposed to OA. ${ }^{\mathrm{a}}: \mathrm{p}<0.01^{\mathrm{b}}: \mathrm{p}<0.001$

\begin{tabular}{|c|c|c|c|c|c|c|}
\hline \multirow{2}{*}{$\begin{array}{l}\text { Treatmert } \\
\text { Groups }\end{array}$} & \multirow{2}{*}{$\begin{array}{l}\text { Nepative } \\
\text { Control }\end{array}$} & \multirow{2}{*}{$\begin{array}{l}\text { Solvent } \\
\text { Control }\end{array}$} & \multirow{2}{*}{$\begin{array}{l}\text { Positive } \\
\text { Control }\end{array}$} & \multicolumn{3}{|c|}{ Osadaic acid } \\
\hline & & & & $1 \mu \mathrm{gg}$ & $5 \mu \mathrm{gkg}$ & $10 \mu \mathrm{g} / \mathrm{kg}$ \\
\hline $24 \mathrm{~b}$ & 0,26 & 0,32 & $1,35 \mathrm{~b}$ & $0,82^{\circ}$ & 1,04 , & $1,34^{b}$ \\
\hline $48 \mathrm{~b}$ & 0,34 & 0,35 & $1,55 \mathrm{~b}$ & 0,90 . & $1.12 *$ & $1,48^{b}$ \\
\hline $72 \mathrm{~b}$ & 0,29 & 0,41 & $1,67^{b}$ & $0.95=$ & $1,20^{\mathrm{b}}$ & $1,65^{b}$ \\
\hline
\end{tabular}

\section{Discussion}

Marine toxins produced by harmful algal blooms present a health risk to humans, but the extent of that risk remains unquantified [16]. Toxins produced by marine algae are accumulated through the food chain and are ultimately deposited in higher predator fish or filter-feeding bivalves. In addition to increasing worldwide seafood consumption, anthropogenic causes may have furthered the spread of the algal toxins. Thus the evaluation of the genotoxic potentials of algal toxins is crucial.

Diarrhetic shellfish poisoning (DSP) is an intoxication associated with the consumption of contaminated shellfish harvested from waters affected by growth of certain types of toxic algae. The most important DSP toxin producers belong to the genus Dinophysis, which produce toxins consisting mostly of OA and its derivatives. DSP has been known for around 30 years and is most common in Europe and Japan, but DSP toxins are being increasingly reported in shellfish from previously unaffected areas. The goal of the present study was to determine if in vivo exposure to $\mathrm{OA}$ cause genotoxic damage in fish. 
Genotoxic effects of OA were previously studied by several authors using different in vivo and in vitro test systems. However, obtained results are rather conflicting. For example Tohda et al, [17] demonstrated that OA treatment significantly increased level of sister chromatid exchange frequencies in human lymphocytes. Similarly Fessard et al., [18] reported that okadaic acid treatments induced DNA adduct formation in BHK21 C13 fibroblasts and HESV keratinocytes. Carvalho Pinto-Silva et al. [19] reported significant increases in MN frequencies in mussel Perna perna, exposed to pure AO. Furthermore Traore et al., [20] visualised DNA strand breaks by the comet assay in OA-treated Caco-2 cells. On the other hand genetic effects of $\mathrm{OA}$ was found to be negative in Salmonella AMES test [21], Hprt mutation test and UDS test in rat hepatocytes [6].

Predatory fish and other marine animals that prey on toxic shellfish may accumulate OA-toxins, especially in liver tissue $[22,23]$. OA accumulation in invertebrates is also reported by Reizopoulou et al., [24]. However there is only a little information regarding the OA concentrations in fish tissues. Accumulation of $\mathrm{OA}$ in fish was first reported by Gamboa $e t$ al. [25] in a carnivorous fish, the barracuda (Sphyraena barracud). Furthermore Sipia et al., [26] analysed the OA content in liver tissues of flounder (Platichthys flesus) from Baltic Sea and reported average value of $222 \mathrm{ng} / \mathrm{g}$ body weight. In the present study it was found that treatment with 1,5 and $10 \mu \mathrm{g} / \mathrm{kg}$ body weight doses of OA-induced significant increases in the frequencies of micronuclei and nuclear buds as well as DNA damage in peripheral erythrocytes of $O$. niloticus.

It is known that the $\mathrm{OA}$ is a tumor promoter. It has been found to inhibit serine/threonine protein phosphatases, especially PP1 and PP2A [27, 28]. Results of previous studies in vitro studies showed that the OA exerts its genotoxic effects via aneugenic mechanism by preventing the chromosome attachments to mitotic spindles [19,29,30]. However, our comet assay results clearly indicated that $\mathrm{OA}$ is capable of inducing DNA strand breaks in fish erythrocytes. Furthermore, we observed significant increases in the formation of nuclear buds, which are considered as an outcome of break-fusion-bridge cycles, following in vivo exposure to OA. Similar DNA damaging effects of OA were also reported in CaCo-2 and V79 cells [20,31]. Furthermore, Le Hegarat et al. [29] suggested that the metabolites of OA could be more cytotoxic and genotoxic than the OA itself as they observed significantly higher amount of genetic damage under metabolic activation conditions in their in vitro studies.

In conclusion, our results demonstrated that in vivo exposure to $\mathrm{OA}$ induce genotoxic damage in fish erythrocytes. Our results further indicate that $\mathrm{OA}$ genotoxicity could be due to aneugenic and clastogenic mode of actions. We suggests that further in vivo and in situ analyses should be performed to better understand long term effects of harmful algal blooms on the genetic structure of fish populations.

\section{References}

[1] E. Sueoka and H.J. Fujiki, "Carcinogenesis of okadaic acid class tumor promoters derived from marine natural products," Cancer Res. Clin. Oncol. 123, 413-419, 1997.

[2] K. Tachibana and P.J. Scheuer, "Okadaic acid, a cytotoxic polyether from two marine sponges of the genus Halichondria," J. Am. Chem. Soc. 103, 2469-2471, 1981.

[3] J. Lee, T. Igarashi, S. Fraga, E. Dahl, P. Hovgaard and T. Yasumoto, "Determination of diarrhetic shellfish toxins in various dinoflagellate species," J. Appl. Phycol. 1, 147-152, 1989.

[4] R. Dickey, S.C. Robzin, D.I. Faulkner and F.Q. Bencsath, “ Identification of okadaic acid from a Caribbean dinoflagellate, Prorocentrum concavum," Toxicon, 28, 371-377, 1990.

[5] H. Nakagawa, S. Kaneko , H. Shima, H. Inamori, H. Fukuda, R. Kominami , T. Sugimura and M. Nagao, "Induction of minisatellite mutation in NIH3T3 cells by treatment with the tumor promoter okadaic acid," Proc. Natl. Acad. Sci. USA, 94, 10813-10816, 1997.

[6] L. Le Hegarat, F. Nesslany, A. Mourot, D. Marzin and V. Fessard, "Lack of DNA damage induction by okadaic acid, a marine toxin, in the CHO-Hprt and the in vitro USD assays" Mutat. Res. 564, 139-147, 2004.

[7] A.G. Bauder, A.D. Cembella, V.M. Bricelj and M.A. Quilliam, "Uptake and fate of diarrhetic shellfish poisoning toxins from the dinoflagellate Prorocentrum lima in the bay scallop Agropecten irradians" Mar. Ecol. Prog. Ser. 213, 39-52, 2001.

[8] K. Al-Sabti and C.D. Metcalfe, "Fish micronuclei for assessing genotoxicity in water," Mutat. Res. 343, 121-135, 1995.

[9] T. Cavas and S. Ergene-Gozukara, "Micronuclei, nuclear lesions and interphase silver stained nucleolar organizer regions (AgNORs) as cytogenotoxicity indicators in Oreochromis niloticus exposed to textile mill effluent," Mutat. Res. 538, 81-91, 2003.

[10] T. Da Silva Souza and C.S. Fontanetti, "Micronucleus test and observation of nuclear alterations in erythrocytes of Nile tilapia exposed to waters affected by refinery effluent," Mutat. Res. 605, 87-93, 2006.

[11] S. Ergene, T. Cavas, A. Celik, N. Köleli and C. Aymak, "Evaluation of river water genotoxicity using the piscine micronucleus test," Environ. Mol. Mutagen. 46, 421-429, 2007.

[12] R.R. Tice, E., Agurell, D. Anderson, B. Burlinson, A. Hartmann, H. Kobayashi, Y. Miyamae, E. Rojas, J.C. Ryu and Y.F. Sasaki, "Single cell gel/comet assay: guidelines for in vitro and in vivo genetic toxicology testing," Environ. Mol. Mutagen. 35, 206-221, 2000.

[13] D. Anderson, T.W. Yu, B.J. Phillips and P. Schezer, "The effect of various antioxidants and other modifying agents on oxygen-radical generated DNA damage in human lymphocytes in the comet assay," Mutat. Res. 307, 261-271, 1994.

[14] J. Palus, E. Dziubaltowska and K. Rydzynski, "DNA damage detected by the comet assay in the white blood cells of workers in a wooden furniture plant," Mutat. Res. 444, 61-74, 1999.

[15] M. Pitarque, A. Creus, R. Marcos, J.A. Hughes and D. Anderson, "Examination of various biomarkers measuring genotoxic endpoints from Barcelona airport personel,” Mutat. Res. 440, 195-204, 1999.

[16] P.L. Krahl, "Harmful algal bloom-associated marine toxins: a risk assessment framework," Arch.Environ.Occup. Health. 64, 129-134, 2009. 
[17] H. Tohda, M. Nagao, T. Sugimura and A. Oikawa, "Okadaic acid, a protein phosphatase inhibitor, induces sister-chromatide exchanges depending on the presence of bromodeoxyuridine," Mutat. Res. 289, 275-280, 1993.

[18] V. Fessard, Y. Grosse, A. Pfohl-Leszkowicz and S. Puiseux-Dao, "Okadaic acid treatment induces DNA adduct formation in BHK21 C13 fibroblasts and HESV keratinocytes," Mutat. Res. 361, 133-141, 1996.

[19] P.S. Carvalho, R. Catia, S. Moukha, W.G. Matias and E.E. Creppy, "Comparative study of domoic acid and Okadaic acid induced chromosomal abnormalities in the CACO-2 cell line. Int. J. Environ. Res. Pub. Health, 3, 4$10,2006$.

[20] A. Traore, I. Baudrimont, S. Ambaliou, S.D. Dano and E.E. Creppy, "DNA breaks and cell cycle arrest induced by okadaic acid in Caco-2 cells, a human colonic epithelial cell line," Arch. Toxicol. 75, 110-117, 2001.

[21] S. Aonuma, T. Ushijima, M. Nakayasu, H. Shima, T. Sugimura and M. Nagao, "Mutation induction by okadaic acid, a protein phosphatase inhibitor, in CHL cells, but not in S. Typhimurium," Mutat. Res. 250, 375-381, 1991.

[22] A. Li, J. Ma, J. Cao and P. McCarron, "Toxins in mussels (Mytilus galloprovincialis) associated with diarrhetic shellfish poisoning episodes in China,"Toxicon 60, 420-425, 2012.

[23] M.V. Prego-Faraldo, C. Valdigleisas, J. Mendez and H.M. Eirin-Lopez, "Okadaic acid meet and greet. An insight into dedection methods, response strageties and genotoxic effects in marine invertebrates," Mar. Drugs 11, 2829-2845., 2103.

[24] S. Reizopoulou, E. Strogyloudi, A. Giannakourou, K. Pagou, I. Hatzianestis, C. Pyrgagi and E. Graneli, "Okadaic acid accumulation in macrofilter feeders subjected to natural blooms of Dinophysis acuminata" Harm. Alg. 7, 228-234, 2008.

[25] P.M. Gamboa, D.L. Park and J.M. Fremya, "Extraction and purification of toxic fractions from Barracuda (Sphyraena barracuda) implicated in ciguatera poisoning.," Proceedings of the Third International Conference on Ciguatera, (T. R. Tosteson, Ed.).Quebec: Polyscience Publications, pp. 13-24, 1992.

[26] V. Sipia, H. Kankaanpaa and J. Meriluoto, "The first observation of okadaic acid in flounder in the Baltic sea," Sarsia 85, 471-471, 2000.

[27] A. Takai, C. Bialojan, M. Troschka and J.C. Ruegg, "Smooth muscle myosin phosphatase inhibition and force enhancement by black sponge toxin," FEBS Lett. 217, 81-84, 1987.

[28] H. Fujiki and M. Suganuma, "Tumor promotion by inhibitors of protein phosphatases 1 and 2A: the okadaic acid class of compounds," Adv. Cancer Res., 61, 143-194, 1993.

[29] L. Le Hegarat, P. Lilian, V. Fessard, J.M. Poul and S. Dragacci, "Aneugenic potential of okadaic acid revealed by the micronucleus assay combined with the FISH technique in CHO-K1 cells," Mutagenesis18, 293298, 2003.

[30] L. Le Hégaratat, T. Orsièreb, A. Bottab and V. Fessarda, "Okadaic acid: Chromosomal non-disjunction analysis in human lymphocytes and study of aneugenic pathway in CHO-K1 cells," Mutat. Res. 578, 53-63, 2005.

[31] C.G. Rogers, C. Heroux-Metcalf and I. Langlois, "Evaluation of cytotoxicity and genotoxicity of okadaic acid, a non-phorbol ester type tumour promoter, in V79 chinese hamster lung cells," Toxicol. In Vitro, 8, 269-276, 1994. 